\title{
An Alkali Activated Binder for High Chemical Resistant Self-Leveling Mortar
}

\author{
Henrik L. Funke, Sandra Gelbrich, Lothar Kroll \\ Institute of Lightweight Structures, Technische Universität Chemnitz, Chemnitz, Germany \\ Email: henrik.funke@mb.tu-chemnitz.de
}

How to cite this paper: Funke, H.L., Gelbrich, S. and Kroll, L. (2016) An Alkali Activated Binder for High Chemical Resistant Self-Leveling Mortar. Open Journal ot Composite Materials, 6, 132-142. http://dx.doi.org/10.4236/ojcm.2016.64013

Received: August 18, 2016

Accepted: October 9, 2016

Published: October 12, 2016

Copyright $\odot 2016$ by authors and Scientific Research Publishing Inc. This work is licensed under the Creative Commons Attribution International License (CC BY 4.0).

http://creativecommons.org/licenses/by/4.0/

\begin{abstract}
This paper reports the development of an Alkali Activated Binder (AAB) with an emphasis on the performance and the durability of the AAB-matrix. For the development of the matrix, the reactive components granulated slag and coal fly ash were used, which were alkali activated with a mixture of sodium hydroxide $(2-10 \mathrm{~mol} / \mathrm{l})$ and aqueous sodium silicate solution $\left(\mathrm{SiO}_{2} / \mathrm{Na}_{2} \mathrm{O}\right.$ molar ratio: 2.1$)$ at ambient temperature. A sodium hydroxide concentration of $5.5 \mathrm{~mol} / \mathrm{l}$ revealed the best compromise between setting time and mechanical strengths of the AAB. With this sodium hydroxide concentration, the compressive and the 3-point bending tensile strengths of the hardened $\mathrm{AAB}$ were 53.4 and $5.5 \mathrm{MPa}$ respectively after 14 days. As a result of the investigation of the acid resistance, the $A A B$-matrix showed a very high acid resistance in comparison to ordinary Portland cement concrete. In addition, the AAB had a high frost resistance, which had been validated by the capillary suction, internal damage and freeze thaw test with a relative dynamic E-Modulus of $93 \%$ and a total amount of scaled material of $30 \mathrm{~g} / \mathrm{m}^{2}$ after 28 freeze-thaw cycles (exposure class: $\mathrm{XF} 3)$.
\end{abstract}

\section{Keywords}

Alkali Activated Binder, Geopolymer, Durability, Chemical Resistance

\section{Introduction}

The increased demand for the development of alternative building materials has been encouraged by the growth of the building industry and the increased performance requirements together with the higher sustainability criteria applied in civil engineering. Alkali Activated Binders ( $\mathrm{AAB}$ ) represent an attractive alternative for the partial or complete substitution of Portland cement in the production of concrete and mortar. The potential benefit from the replacement of Portland cement by AAB is the reduction 
in carbon dioxide emissions. The production of 1 ton of Portland cement releases approximately 1 ton of carbon dioxide and requires about $100 \mathrm{kWh}$ [1] [2]. As opposed to this, the production of 1 ton of $\mathrm{AAB}$ creates only between 0.2 and 0.5 ton of carbon dioxide [3]-[5]. In comparison with composite cements or slag cements, the AAB is the better ecological solution as long as the amount of Portland cement is more than 50\% by mass. Thereby, they offer more green benefits than commonly used

CEM II shows a minimum Portland cement portion of $65 \%$ by mass. Beyond this, $\mathrm{AAB}$ points up a high mechanical strength, a high temperature and fire resistance, an acid resistance and a low shrinkage [6]-[8]. Various scientific reports concerning the microstructure of different $A A B$ are available [9] [10]. Several current studies deal with the production of $A A B$ and their durability properties [11] [12]. The durability is a very controversial property of AAB. Some authors state it as the most important advantage over Portland cement, while others consider that as an unverified statement [13]-[15]. Similar to concrete, where a combination of mechanical and environmental loading can lead to the deterioration of mechanical properties, the durability of AAB is limited by material properties like water permeability, porosity, sorptivity, sulphate resistance, chloride ion penetration, carbonation, corrosion resistance, drying shrinkage and acid resistance [13] [15].

Actually, in comparison to Portland cement, the results of the latest research demonstrate better mechanical properties and durability under aggressive conditions for numerous reaction products made of $\mathrm{AAB}$ [16]-[21]. Furthermore, the investigations of Weil et al. show an outstanding durability for selective optimized AAB [22]. Malone already showed an enhanced frost resistance of $\mathrm{AAB}$ due to a comparatively high density and reduced porosity [23]. However, a noteworthy point is the formation of efflorescence products when $\mathrm{AAB}$ products are in contact with water or humidity [23]-[26]. The elution of the alkalis and their reaction with atmospheric carbon dioxide can lead to the formation of carbonates which appear as efflorescence on the surface [24] [25] [27]. An improvement of the durability can be implemented by a high amount of amorphous zeolite phases in the product realized by an adapted silicate modulus [28].

Alkali activated binders are prepared by the alkaline activation of aluminosilicate materials such as fly ash, granulated slag or calcined clays [7] [29], and cured at ambient or slightly higher temperature [30] [31]. The alkaline activation, which comprises the solving process, polymerization and crystallization, depends on many parameters, including chemical composition, physical properties (e.g. particle size distribution and specific surface area of the raw materials), composition of alkaline solution and curing temperature [32] [33]. According to the law of mass action, the amount of amorphous phases formed by the reaction increases with increasing concentration of the alkaline solution [34]. Therefore, strength and durability increase, too [35]. For a further enhancement of mechanical properties of the $\mathrm{AAB}$, short fibres can be integrated [36] [37].

This paper presents results of the development of an AAB-matrix with an emphasis on the measurement of the performance and durability of AAB-matrix. 


\section{Materials and Methods}

\subsection{Components for Alkali Activated Binders}

In this study, the alkali activated binders were compared with an ordinary Portland cement concrete (OPCC). The compositions of the alkali activated binders are present in Table 1. For the reactive binders, the coal fly ash (bulk density: $2.42 \mathrm{~g} / \mathrm{cm}^{3}$ ) "EFA-Füller" (class F) by the company Bauminerale $\mathrm{GmbH}$ and a granulated slag (bulk density: $2.85 \mathrm{~g} / \mathrm{cm}^{3}$ ) by the company Holcim were used. The oxides compositions of the coal fly ashes and slag were determined by energy dispersive X-ray spectroscopy (EDX) and are shown in Table 2. The measured Blaine fineness of the coal fly ash and of the granulated slag was 7290 and $3740 \mathrm{~cm}^{2} / g$ respectively. A quartz sand with a grain size of 0.1 to $1.0 \mathrm{~mm}$ was used as aggregate. The alkali resistant (AR) glass fibres, which lower the propensity to shrinkage cracking and can enhance first crack tensile strength in the concrete, were $12 \mathrm{~mm}$ long and had a length mass of 45 tex. The activator solutions consisted of a mixture of aqueous sodium silicate $\left(\mathrm{SiO}_{2} / \mathrm{Na}_{2} \mathrm{O}\right.$ molar ratio: 2.1$)$ and a solution of sodium hydroxide.

The sodium hydroxide solution was prepared by dissolving sodium hydroxide pellets (99\% purity) in distilled water to a concentration of $2-10 \mathrm{~mol} / \mathrm{l}$ and cooled to room temperature for $24 \mathrm{~h}$. The water/binder ratio was 0.41 .

Table 1. Composition of AAB and OPCC in wt\%.

\begin{tabular}{|c|c|c|}
\hline & $\mathrm{AAB}$ & OPCC \\
\hline Granulated slag & 22.5 & - \\
\hline Coal fly ash & 9.0 & - \\
\hline CEM I 52.5 & - & 22.7 \\
\hline Quartz sand $0-2 \mathrm{~mm}$ & 49.3 & 68.9 \\
\hline $\mathrm{NaOH}$-solution & 13.7 & - \\
\hline Sodium silicate & 4.5 & - \\
\hline AR-glass fibres & & \\
\hline Superplasticizer & - & 0.6 \\
\hline $\mathrm{w} / \mathrm{b}$ & & \\
\hline
\end{tabular}

Table 2. Oxides compositions of coal fly ash and granulated slag in wt\%.

\begin{tabular}{ccc}
\hline & Coal fly ash & Granulated slag \\
\hline $\mathrm{SiO}_{2}$ & 45 & 52 \\
$\mathrm{Al}_{2} \mathrm{O}_{3}$ & 10 & 30 \\
$\mathrm{Fe}_{2} \mathrm{O}_{3}$ & - & 10 \\
$\mathrm{CaO}$ & 35 & 5 \\
$\mathrm{MgO}$ & 10 & 3 \\
\hline
\end{tabular}




\subsection{Sample Preparation}

The sodium hydroxide solution and the aqueous sodium silicate were stirred for $15 \mathrm{~min}$ by a magnetic stirrer. After that, the $\mathrm{AAB}$ specimens were manufactured by adding the activator solutions to the solid precursor (coal fly ash. granulated slag and aggregates). Then, all specimens were produced by mechanical mixing for $4 \mathrm{~min}$. Subsequently, the AR-glass fibres were added to the fresh $\mathrm{AAB}$ and mixed together for $0.5 \mathrm{~min}$. The detailed mixing proportion properties are shown in Table 3.

For the structural study of hardened $\mathrm{AAB}$, the specimens were cast into corresponding molds and cured at a temperature of $20^{\circ} \mathrm{C}$ and a relative humidity of $65 \%$ for 24 hours. Following this, the samples for the tests to be performed on the hardened concrete were stored dry, according to EN 12390-2.

\subsection{Test Set-Up}

The 3-point bending tensile strength was determined by means of the Toni Technik ToniNorm (load frame $20 \mathrm{kN}$ ) with three samples measuring $160 \times 40 \times 40 \mathrm{~mm}^{3}$ (length $\times$ width $\times$ height), based on EN12390-5 (Figure 1(a)). The compressive strength was determined by means of the Toni Technik ToniNorm (load frame 3000 $\mathrm{kN}$ ) following EN 12390-3, with three cubes having an edge length of $150 \mathrm{~mm}$ (Figure 1 (b)). The pre-load and the loading speed were $18 \mathrm{kN}$ and $0.5 \mathrm{~mm} / \mathrm{min}$ respectively.

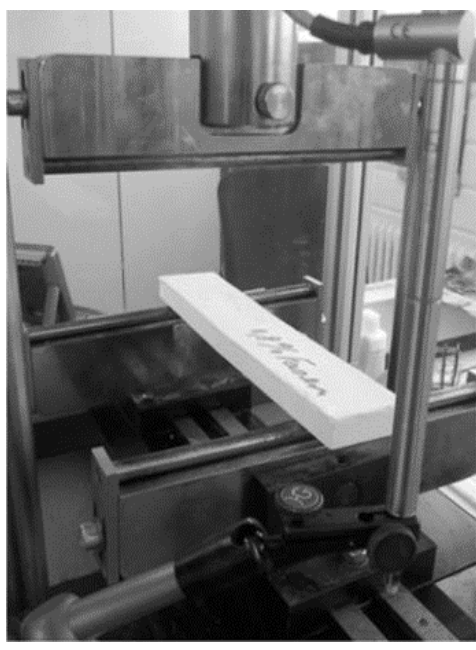

(a)

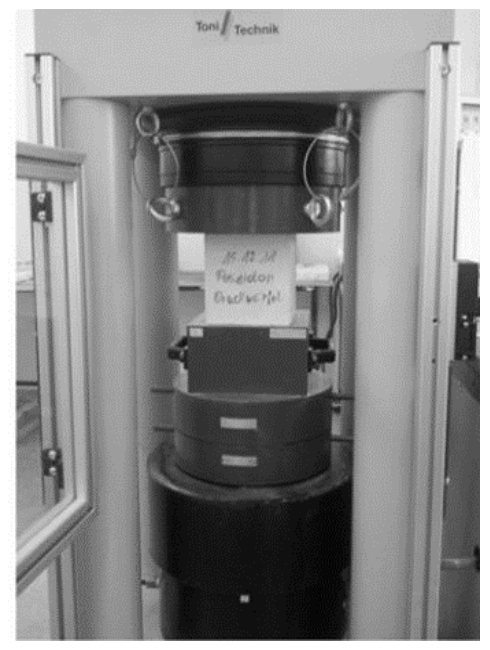

(b)

Figure 1. Determination of 3-point bending tensile (a) and compressive strength (b).

Table 3. Composition of AAB and OPCC in wt\%.

\begin{tabular}{|c|c|c|c|c|}
\hline & Component & $\begin{array}{l}\text { Mixing } \\
\text { technology }\end{array}$ & $\begin{array}{l}\text { Mixing power } \\
\text { in } \%\end{array}$ & $\begin{array}{l}\text { Mixing time } \\
\text { in } s\end{array}$ \\
\hline 1st & Binders + aggregates & concurrent & 15 & 60 \\
\hline 2nd & Activator solution + solid precursor & sequence & 40 & 240 \\
\hline $3 r d$ & AR-glass fibres & sequence & 40 & 30 \\
\hline
\end{tabular}


To quantify the durability of the AAB-matrix, the freeze-thaw test, the water permeability and the acid resistance were investigated. The freeze-thaw test was measured with the CIF-Test (Capillary suction, Internal damage and Freeze-thaw test) by the Schleibinger Freeze-Thaw-Tester with standard agent solution according to the recommendations of RILEM TC 176 IDC (Figure 2(a)). The acid resistance was determined by the mass loss after storage of three specimens ( 28 days old) in $37 \%$ hydrochloric acid for 7 days at a temperature of $21^{\circ} \mathrm{C}$ (Figure 2(b)). The determination of the water permeability was carried out according to DIN EN 1062-3 (Figure 2(c)).

\section{Results and Discussion}

\subsection{Properties of AAB}

Table 4 reveals the fresh and hardened AAB characteristics at the age of 14 days. Using an air content tester, a gross geometric density of $2.39 \mathrm{~g} / \mathrm{cm}^{3}$ and air content of 2.4 volume percent and were determined in the fresh $\mathrm{AAB}$. The 3-point bending tensile and compressive strengths of the hardened $\mathrm{AAB}$ were 5.5 and $53.4 \mathrm{MPa}$ respectively. The $\mathrm{pH}$-value of the fresh $\mathrm{AAB}$ was 14 , whereby the $\mathrm{pH}$-value decreased to 10 due to the reactions in the hardened $\mathrm{AAB}$. A dynamic elastic modulus of $36 \mathrm{GPa}$ was determined by the ultrasonic examination. The total shrinkage deformation was $0.45 \mathrm{~mm} / \mathrm{m}$.

Furthermore to the reactivity and the solids content of the alkali activated binders, the amount and concentration of the alkaline activator have an influence on the solubility and reactivity of the $\mathrm{AAB}$ [38]. For this influence, the 3-point bending tensile

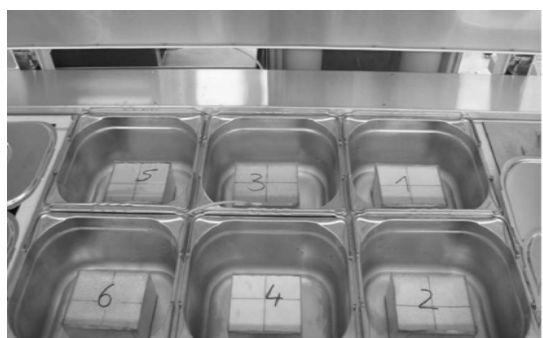

(a)

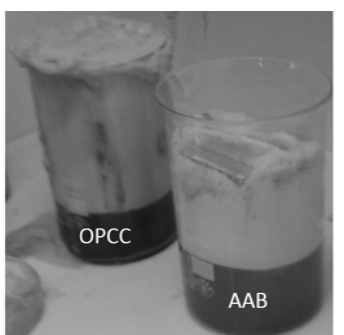

(b)

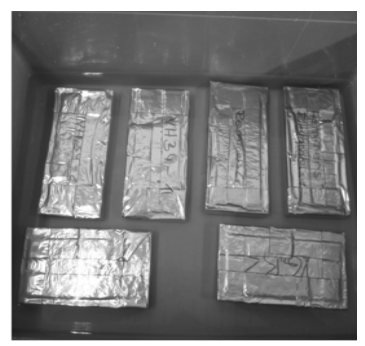

(c)

Figure 2. (a) CIF-Test; (b) Acid storage; (c) Water absorption.

Table 4. Basic properties of fresh and hardened AAB (NaOH: $5.5 \mathrm{~mol} / \mathrm{l})$.

\begin{tabular}{ccc}
\hline & Fresh AAB & Hardened AAB \\
pH-value & $2.39 \mathrm{~g} / \mathrm{cm}^{3}$ & $2.35 \mathrm{~g} / \mathrm{cm}^{3}$ \\
Compressive strength & 14 & 10 \\
3-p. bending tensile strength & - & $53.4 \mathrm{MPa}$ \\
Elastic modulus (dynamic) & - & $5.5 \mathrm{MPa}$ \\
Total shrinkage & - & $36 \mathrm{GPa}$
\end{tabular}


strength (after seven days) is shown as a function of the $\mathrm{NaOH}$ concentration (1.2 to $10.0 \mathrm{~mol} / \mathrm{l}$ ) in Figure 3. Referring to Figure 3, an increase of the sodium hydroxide concentration leads to an increase of the 3-point bending tensile strength. The sodium hydroxide concentration of over $5.5 \mathrm{~mol} / \mathrm{l}$ did not further increase the 3-point bending tensile strength, because the saturation point with respect to the solubility of the binder was reached, thus leading to a high level of degree of reaction. Sodium hydroxide concentrations over $5.5 \mathrm{~mol} / \mathrm{l}$ did not result in an increasing of the 3-point bending tensile strength after seven days.

\subsection{Thermogravimetry}

The thermogravimetry and the differential thermogravimetry of the AAB-matrix are illustrated in Figure 4. Regarding to Figure 4, it can be observed that the weight loss started at a temperature of $35^{\circ} \mathrm{C}$ with maximum weight loss at $87^{\circ} \mathrm{C}$. This weight loss can be attributed to the removal of free and unbound absorbed water molecules. The further mass loss up to a temperature of about $300^{\circ} \mathrm{C}$ corresponded to the physically bound water in the porous matrix and the zeolite-water from the nanocrystalline zeolite structures [39] [40]. The mass loss up to a temperature of around $520^{\circ} \mathrm{C}$ resulted from the decomposition of the chemically bound water from the calcium silicate and the calcium aluminate phases. The cumulated weight loss was of $10.5 \%$ at a temperature of $900^{\circ} \mathrm{C}$

\subsection{Durability of AAB Matrix}

The results of the durability of the alkali activated binder were investigated and the comparison with the ordinary Portland cement concrete is shown in Table 5. The results comprise the freeze-thaw test, the water permeability and the acid resistance. The AAB-matrix had a water absorption coefficient $\left(\mathrm{w}_{\mathrm{t}}\right)$ of $0.095 \mathrm{~kg} / \mathrm{m}^{2} \cdot \mathrm{h}^{0.5}$ and reached the class 3 (low water absorption) according to DIN EN 1062-3 (Table 5). As opposed to this, the OPCC had a water absorption coefficient of $1.301 \mathrm{~kg} / \mathrm{m}^{2} \cdot \mathrm{h}^{0.5}$ and reached the class 1 (high water absorption).

Table 5. Results of the durability of AAB and OPCC.

\begin{tabular}{ccc}
\hline & $\mathrm{AAB}$ & OPCC \\
\hline Water absorption coefficient & 0.095 & 1.301 \\
$\mathrm{w}_{\mathrm{t}}$ in $\mathrm{kg} / \mathrm{m}^{2} \cdot \mathrm{h}^{0.5}$ & 3 & 1 \\
Class (DIN EN 1062-3) & & \\
Acid resistance & 15.9 & 75.1 \\
Weight loss in \% & & \\
CIF-Test & 96 & 91 \\
$\mathrm{Ru}_{28}$ in $\%$ & 30 & 217 \\
$\mathrm{~m}_{28}$ in $\mathrm{g} / \mathrm{m}^{2}$ & & \\
\hline
\end{tabular}




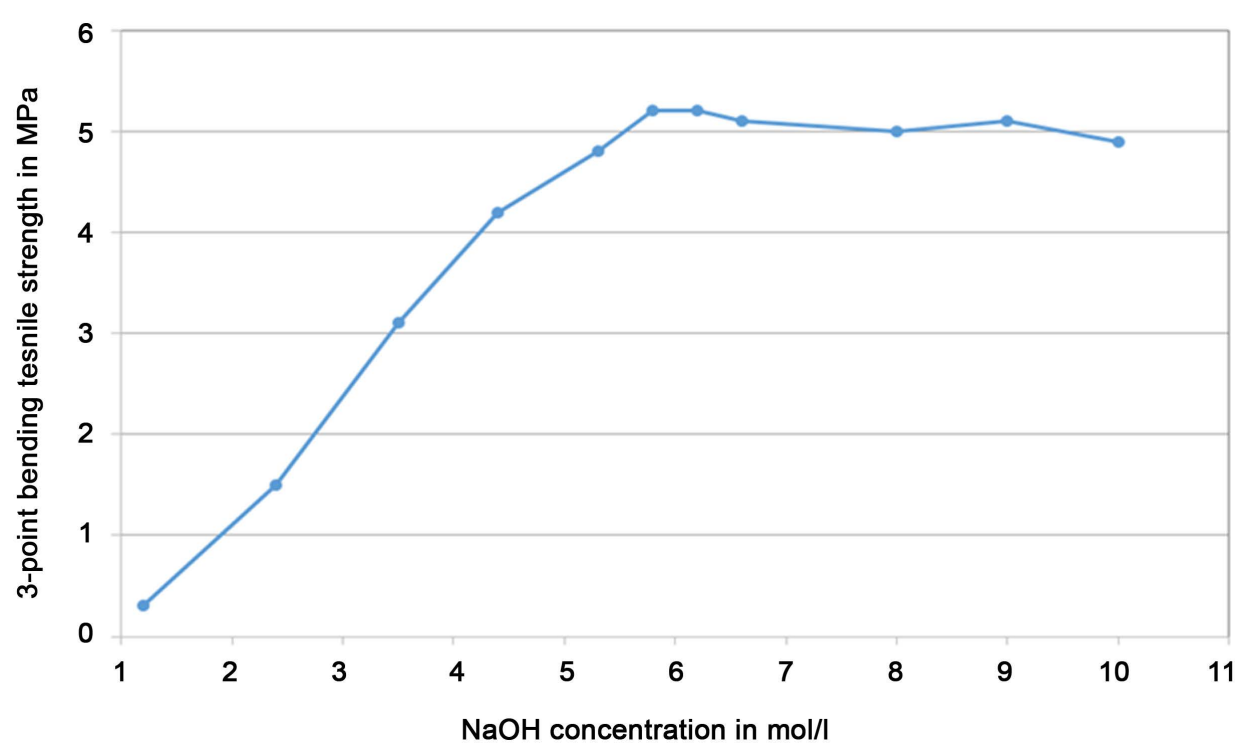

Figure 3. 3-point bending tensile strength as a function of the $\mathrm{NaOH}$ concentration.

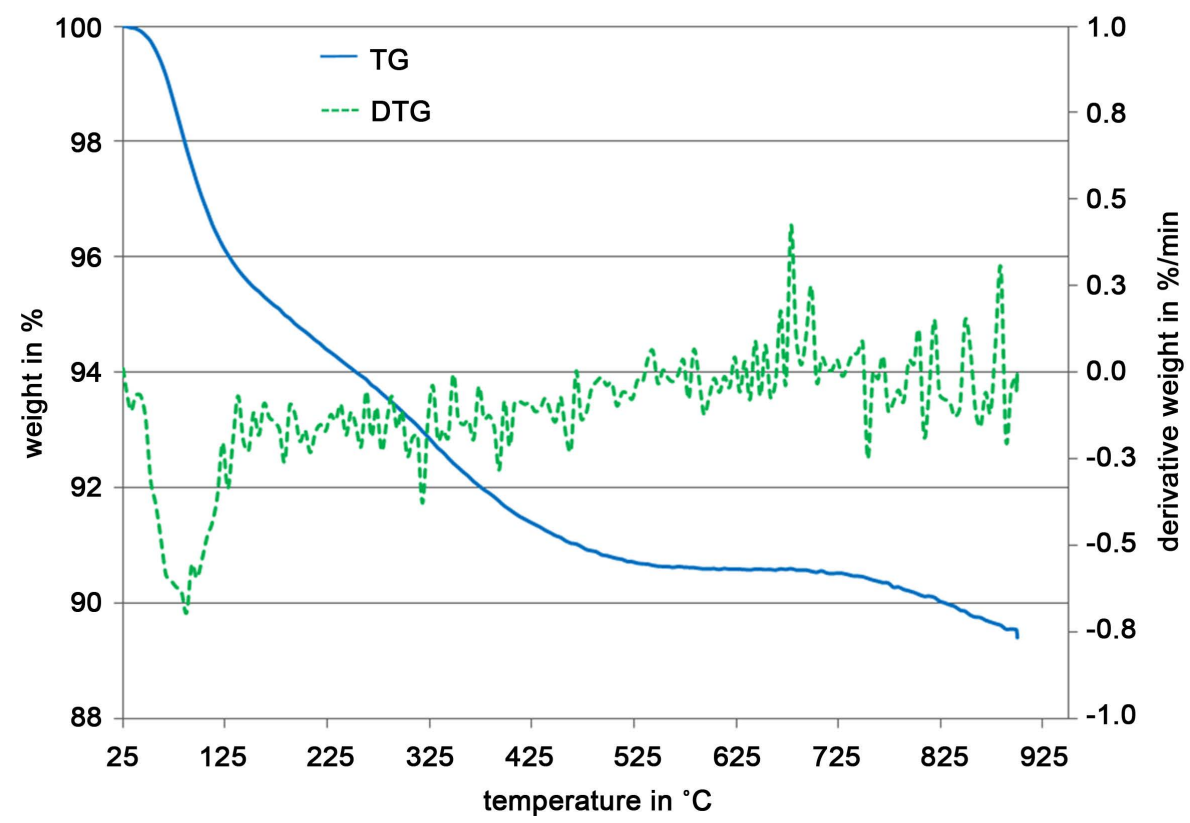

Figure 4. Thermogravimetry and the differential thermogravimetry of the AAB.

In addition, the $\mathrm{AAB}$-matrix exhibited a high frost resistance, which was verified through a successful CIF test with a relative dynamic modulus of elasticity of 93 percent $(\mathrm{Ru}, 28)$ and an average scaling of $30 \mathrm{~g} / \mathrm{m}^{2}\left(\mathrm{~m}_{28}\right)$ after 28 freeze-thaw cycles (Table 5 and Figure 5).

After seven days storage in $37 \%$ hydrochloric acid, the AAB-matrix had a mass loss of 15.9\% (see Table 5 and Figure 6). In comparison, the mass loss of the OPCC was significantly higher with $75.9 \%$. The high acid resistance of the AAB-matrix is mainly due to the portlandite-free phases. 


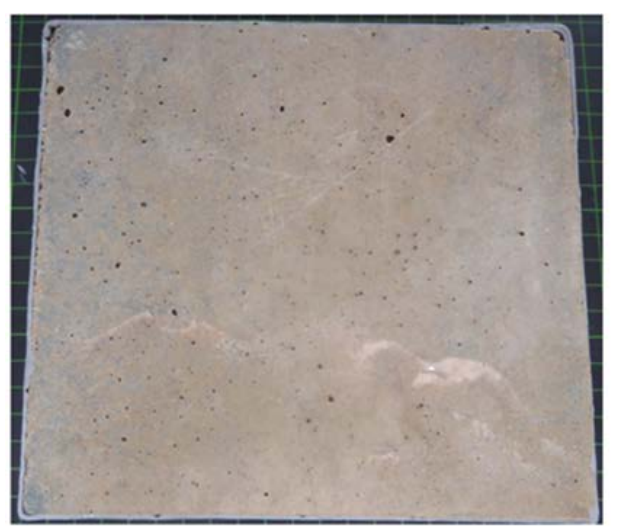

(a)

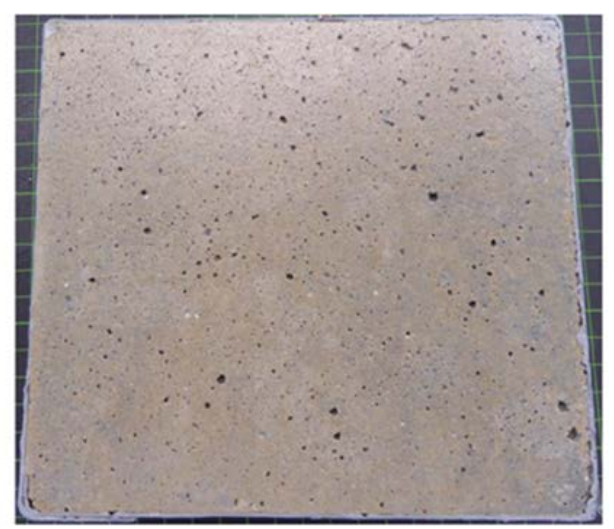

(b)

Figure 5. Test surface before (a) and after (b) the CIF-Test.
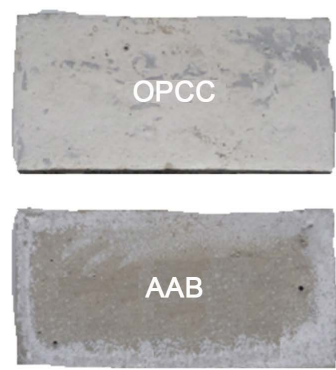

\section{7 days acid attack}
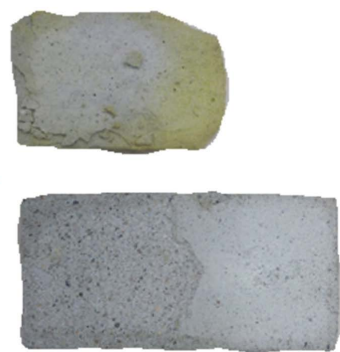

Figure 6. AAB and OPCC samples before (left) and after the acid attack (right).

\section{Conclusions}

In this study herein, the development of an $\mathrm{AAB}$-matrix and the performance and durability of different fibres in the $\mathrm{AAB}$-matrix were investigated through various experimental work. Based on the results of this study, the following key points are drawn:

- The adapted molarity of the sodium hydroxide solution was $5.5 \mathrm{~mol} / \mathrm{l}$. Sodium hydroxide concentrations over $5.5 \mathrm{~mol} / 1$ did not result in an increasing of the 3-point bending tensile strength after seven days,

- The AAB achieved a compressive and a 3-point bending tensile strength of 53.4 and $5.5 \mathrm{MPa}$ respectively after one day at ambient temperatures,

- The acid resistance of the AAB was 500\% higher than the ordinary Portland cement concrete, which could be attributed mainly to the free portlandite phases.

\section{Acknowledgements}

This work was supported by the German Federation of Industrial Research Associations (AiF). The authors would like to acknowledge with gratitude the foundation's financial support.

\section{References}

[1] Purnell, P. (2011) Material Nature versus Structural Nurture: The Embodied Carbon of Fundamental Structural Elements. Environmental Science \& Technology, 46, 454-461. 
http://dx.doi.org/10.1021/es202190r

[2] IEA (2009) Cement Technology Roadmap 2009. Carbon Emissions Reductions up to 2050.

[3] McLellan, B.C., Williams, R.P., Lay, J., van Riessen, A. and Corder, G.D. (2011) Costs and Carbon Emissions for Geopolymer Pastes in Comparison to Ordinary Portland Cement. Journal of Cleaner Production, 19, 1080-1090. http://dx.doi.org/10.1016/j.jclepro.2011.02.010

[4] Davidovits, J. (1993) Geopolymer Cements to Minimise Carbon Dioxide Greenhouse Warming. Ceramic Transactions, 37, 165-182.

[5] Komnitas, K. and Zaharaki, D. (2007) Geopolymerisation: A Review and Prospects for the Minerals Industry. Minerals Engineering, 20, 1261-1277. http://dx.doi.org/10.1016/j.mineng.2007.07.011

[6] Shi, C., Jimenez, A. and Palomo, A. (2011) New Cements for the 21st Century: The Pursuit of an Alternative to Portland Cement. Cement and Concrete Research, 41, 750-763. http://dx.doi.org/10.1016/j.cemconres.2011.03.016

[7] Bernal, S.A., et al. (2014) MgO Content of Slag Controls Phase Evolution and Structural Changes Induced by Accelerated Carbonation in Alkali-Activated Binders. Cement and Concrete Research, 57, 33-43. http://dx.doi.org/10.1016/j.cemconres.2013.12.003

[8] Funke, H. and Gelbrich, S. (2015) Alkalisch aktivierte Bindemittel zur Generierung von faserverstärkten Vergussmassen. 19. Ibausil, Weimar, 16-18 September 2015, Band 1, 859866.

[9] Murmu, M. and Singh, A. (2014) Hydration Products, Morphology and Microstructure of Activated Slag Cement. International Journal of Concrete Structures and Material, 8, 61-68.

[10] Kar, A., Ray, I., Halabe, U.B., Unnikrishnan, A. and Dawson-Andoh, B. (2014) Characterizations and Quantitative Estimation of Alkali-Activated Binder Paste from Microstructures. International Journal of Concrete Structures and Materials, 8, 213-228. http://dx.doi.org/10.1007/s40069-014-0069-0

[11] Provis, J.L. (2014) Geopolymers and Other Alkali Activated Materials: Why, How, and What? Materials and Structures, 47, 11-25. http://dx.doi.org/10.1617/s11527-013-0211-5

[12] Vance, K., Aguayo, M., Dakhane, A., Ravikumar, D., Jain, J. and Neithalath, N. (2014) Microstructural, Mechanical, and Durability Related Similarities in Concretes Based on OPC and Alkali-Activated Slag Binders. International Journal of Concrete Structures and Materials, 8, 289-299. http://dx.doi.org/10.1007/s40069-014-0082-3

[13] Sakulich, A.R. (2011) Reinforced Geopolymer Composites for Enhanced Material Greenness and Durability. Sustainable Cities and Society, 1, 195-210. http://dx.doi.org/10.1016/j.scs.2011.07.009

[14] Pacheco-Torgal, F., Castro-Gomes, J. and Jalali, S. (2008) Alkali-Activated Binders: A Review Part 1. Historical Background, Terminology, Reaction Mechanisms and Hydration Products. Construction and Building Materials, 22, 1305-1314. http://dx.doi.org/10.1016/j.conbuildmat.2007.10.015

[15] Hossain, M., Karim, M.R., Hossain, M.K., Islam, M.N. and Zain, M.F.M. (2015) Durability of Mortar and Concrete Containing Alkali-Activated Binder with Pozzolans: A Review. Construction and Building Materials, 93, 95-109. http://dx.doi.org/10.1016/j.conbuildmat.2015.05.094

[16] Bondar, D., Lynsdale, C.J., Milestone, N.B. and Hassani, N. (2015) Sulfate Resistance of Alkali Activated Pozzolans. International Journal of Concrete Structures and Materials, 9, 145-158. http://dx.doi.org/10.1007/s40069-014-0093-0 
[17] Pacheco-Torgal, F. and Jalali, S. (2011) Resistance to Acid Attack, Abrasion and Leaching Behavior of Alkali-Activated Mine Waste Binders. Materials and Structures, 44, 487-498. http://dx.doi.org/10.1617/s11527-010-9643-3

[18] Deb, P., Nath, P. and Sarker, P. (2014) The Effects of Ground Granulated Blast-Furnace Slag Blending with Fly Ash and Activator Content on the Workability and Strength Properties of Geopolymer Concrete Cured at Ambient Temperature. Materials and Design, 62, 3239. http://dx.doi.org/10.1016/j.matdes.2014.05.001

[19] Ismai, I., Bernal, S.A., Provis, J.L., Hamdan, S. and van Deventer, J.S.J. (2011) Microstructural Changes in Alkali Activated Fly Ash/Slag Geopolymers with Sulfate Exposure. Materials and Structures, 46, 361-373. http://dx.doi.org/10.1617/s11527-012-9906-2

[20] Ismail, I., et al. (2013) Influence of Fly Ash on the Water and Chloride Permeability of Alkaliactivated Slag Mortars and Concretes. Construction and Building Materials, 48, 11871201. http://dx.doi.org/10.1016/j.conbuildmat.2013.07.106

[21] Yang, T., Yao, X. and Zhang, Z. (2014) Quantification of Chloride Diffusion in Fly AshSlag-Based Geopolymers by X-Ray Fluorescence (XRF). Construction and Building Materials, 69, 109-115. http://dx.doi.org/10.1016/j.conbuildmat.2014.07.031

[22] Weil, M., Dombrowski-Daube, K. and Buchwald, A. (2011) Geopolymer Binders-Part 3: Ecological and Economic Analyses of Geopolymer Concrete Mixes for External Structural Elements. ZKG International, 64, 76-87.

[23] Malone, P., Randall, C. and Kirkpatrick, T. (1985) Potential Applications of Alkali-Activated Alumino-Silicate Binders in Military Operations. US Army Corps of Engineers, Miscellaneous Paper.

[24] Kani, E., Allahverdi, A. and Provis, J. (2011) Efflorescence Control in Geopolymer Binders Based on Natural Pozzolan. Cement and Concrete Composites, 34, 25-33. http://dx.doi.org/10.1016/j.cemconcomp.2011.07.007

[25] Zhang, Z., Provis, J.L., Reid, A. and Wang, H. (2014) Fly Ash-Based Geopolymers: The Relationship between Composition, Pore Structure and Efflorescence. Cement and Concrete Research, 64, 30-41. http://dx.doi.org/10.1016/j.cemconres.2014.06.004

[26] Yao, X., Yang, T. and Zhang, Z. (2015) Compressive Strength Development and Shrinkage of Alkaliactivated Fly Ash-Slag Blends Associated with Efflorescence. Material and Structures, 49, 2907-2918. http://dx.doi.org/10.1617/s11527-015-0694-3

[27] Fiala, C., Mukarovsky, J. and Kynclova, M. (2008) Material Effective Structures-The Way towards Sustainable Buildings. Proceedings of the Conference on Sustainable Building SBO8 Melbourne, Melbourne, 21-25 September 2008, 196-203.

[28] Pacheco-Torgal, F., Abdollahnejad, Z., Camões, A.F., Jamshidic, M. and Ding, Y. (2012) Durability of Alkali-Activated Binders: A Clear Advantage over Portland Cement or an Unproven Issue? Construction and Building Materials, 30, 400-405. http://dx.doi.org/10.1016/j.conbuildmat.2011.12.017

[29] Damtoft, J., Lukasik, J., Herfort, D., Sorrentino, D. and Gartner, E.M. (2008) Sustainable Development and Climate Change Initiatives. Cement and Concrete Research, 38, 115-127. http://dx.doi.org/10.1016/j.cemconres.2007.09.008

[30] Davidovits, J. (1991) Geopolymers: Inorganic Polymeric New Materials. Journal of Thermal Analysis, 37, 1633-1656. http://dx.doi.org/10.1007/BF01912193

[31] Cheng, T.W. (2010) Development and Application of Geopolymer Technology: A Review. Mining and Metallurgy, 54, 141-157.

[32] Schneider, M., Romer, M., Tschudin, M. and Bolio, H. (2011) Sustainable Cement Production-Present and Future. Cement and Concrete Research, 41, 642-650. 
http://dx.doi.org/10.1016/j.cemconres.2011.03.019

[33] Duxson, P., Provis, J.L., Lukey, G.C. and van Deventer, J.S.J. (2007) The Role of Inorganic polymer Technology in the Development of Green Concrete. Cement Concrete Research, 37, 1590-1597. http://dx.doi.org/10.1016/j.cemconres.2007.08.018

[34] Duxson, P., Lukey, G. and van Deventer, J. (2007) The Thermal Evolution of Metakaolin Geopolymers: Part 2-Phase Stability and Structural Development. Journal of Non-Crystalline Solids, 352, 5541-5555. http://dx.doi.org/10.1016/j.jnoncrysol.2006.09.019

[35] Wang, H., Li, H. and Yan, F. (2005) Synthesis and Mechanical Properties of Metakaolinite-Based Geopolymer. Colloids and Surfaces A: Physiochemical and Engineering Aspects, 268, 1-6. http://dx.doi.org/10.1016/j.colsurfa.2005.01.016

[36] Li, W. and Xu, J. (2009) Mechanical Properties of Basalt Fibre Reinforced Geopolymeric Concrete under Impact Loading. Materials Science Engineering, 505, 178-186. http://dx.doi.org/10.1016/j.msea.2008.11.063

[37] Funke, H., Gelbrich, S., Ehrlich, A. and Kroll, L. (2014) Rheological and Mechanical Development of a Fiber-Reinforced Concrete for an Application in Civil Engineering. SOJ Materials Science \& Engineering, 2, 1-4. http://dx.doi.org/10.15226/sojmse.2014.00111

[38] Buchwald, A. (2012) Der Einfluss des Kalziums auf die Kondensation von (Alumo-)Silikaten in alkali-aktivierten Binder. Habilitation Thesis, Gemeinsamer Bibliotheksverbund, Erfurt.

[39] Provis, J., Lukey, G. and Deventer, J. (2005) Do Geopolymers Actually Contain Nanocrystalline Zeolites? A Reexamination of Existing Results. Chemistry of Materials, 17, 30753085. http://dx.doi.org/10.1021/cm050230i

[40] Bernal, S. (2011) Mechanical and Thermal Characterization of Geopolymers Based on Silicate Activated Metakaolin/Slag Blends. Journal Material Science, 46, 5477-5486. http://dx.doi.org/10.1007/s10853-011-5490-z

Submit or recommend next manuscript to SCIRP and we will provide best service for you:

Accepting pre-submission inquiries through Email, Facebook, LinkedIn, Twitter, etc.

A wide selection of journals (inclusive of 9 subjects, more than 200 journals)

Providing 24-hour high-quality service

User-friendly online submission system

Fair and swift peer-review system

Efficient typesetting and proofreading procedure

Display of the result of downloads and visits, as well as the number of cited articles

Maximum dissemination of your research work

Submit your manuscript at: http://papersubmission.scirp.org/

Or contact ojcm@scirp.org 